\title{
Subjective contours 1900-1990: Research trends and bibliography
}

\author{
FRANCO PURGHÉ \\ Università di Roma "La Sapienza," Rome, Italy \\ and \\ STANLEY COREN \\ University of British Columbia, Vancouver, British Columbia, Canada
}

\begin{abstract}
A bibliography on subjective contours and a brief summary of trends in research on this problem are presented. The bibliography covers the years 1900-1990 and contains 445 entries, each briefly annotated with a code that indicates the general content and theoretical orientation of the item.
\end{abstract}

Subjective contours, illusory contours, phenomenal contours, anomalous contours, and quasiperceptive margin figures are all terms that refer to the perception of contours, lines, edges, or surfaces that are not physically present in the stimulus array. Over the past 15 years, they have become one of the most widely studied of the illusory phenomena in vision. In 1985, work on subjective contours had become so widespread that an international conference exclusively devoted to the topic was held in New York (see Petry \& Meyer, 1987a).

Although a number of researchers, including Helmholtz, Wundt, Ebbinghaus, Sanford, and Titchner all published figures in which subjective contours appear to be quite evident to us today, they made no comments about them. In 1900, Schumann published the first figure that was specifically used to describe the phenomenon. In that paper too, the first use of the term subjective to describe the contours and lines so formed occurs. Yet although a few textbooks and monographs reprinted Schumann's subjective contour figure, there was very little systematic work on the phenomenon for some 55 years after its initial description.

In 1955, Kanizsa presented an analysis of subjective contour figures, in which he used a series of new and more powerful variants of the initial Schumann configuration.

\footnotetext{
This research was supported in part by a grant from the Natural Sciences and Engineering Research Council of Canada. For reprints or other correspondence, contact F. Purghé, Dipartimento di Psicologia, Università di Roma "La Sapienza," Via degli Apuli, 800185 Rome, Italy, or S. Coren, Department of Psychology, University of British Columbia, 2136 West Mall, Vancouver, BC, Canada V6T 1Z4. Phone: (604) 822-6458. Fax: (604) 822-6923. For a disk copy of the bibliography in PC DOS or Macintosh format, please send an appropriately formatted disk and a self-addressed mailer (along with an indication of format desired) to $\mathrm{S}$. Coren at the address above.
}

Yet although this is now the most frequently cited work on subjective contours, it did not have much of an initial effect. This was probably because it was published in Italian, in a journal of rather limited circulation. Thus the initial interest in the phenomenon was confined to a few Italian phenomenological psychologists who were closely associated with the traditions of the Institute of Psychology chaired by Kanizsa at the University of Trieste.

For subjective contour research, 1972 was an important year: two articles about subjective contours appeared in English, in widely distributed journals. Coren (1972), in addition to calling attention to Kanizsa's work, offered his "implicit depth cue" theory in Psychological Review. Gregory (1972), in a short report in Nature, presented variants of Kanizsa's figures and offered his "object hypothesis" model. Following these publications, there was an

\section{Number of Subjective Contour Publications}

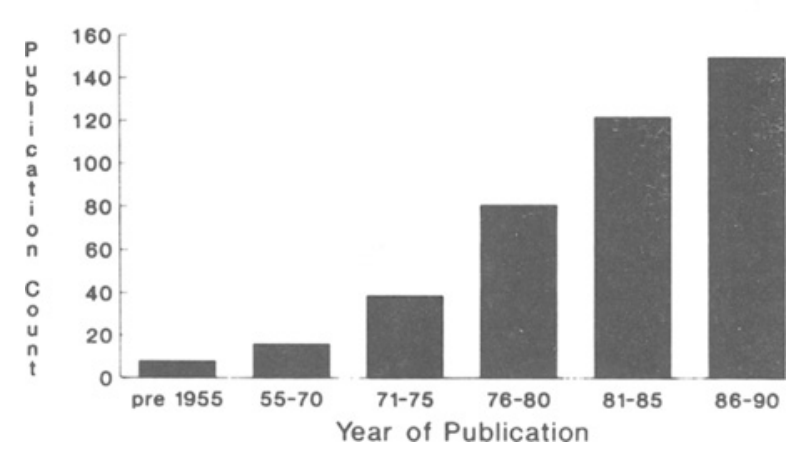

Figure 1. Number of publications dealing with subjective contours from 1900 to 1990 . 
immediate spurt of activity, with researchers both studying subjective contours for their own sake and using them as methodological tools to explore other issues in visual perception. The number of publícations that dealt directly with subjective contours has steadily increased, as can be seen in Figure 1. In the 5-year period from 1986 to 1990, there were nearly 150 new entries in the literature on this topic.

To provide a research tool for investigators who wish to pursue studies on subjective contours, we decided to compile as complete a bibliography as possible on this topic. In addition, to facilitate the gathering of information about specific aspects of the problem, we decided to include a brief form of content annotation. The literature search period functionally begins in 1900 (when Schumann first mentioned the topic), although a few items in which the phenomenon is mentioned in passing, from before 1900 , are also included. The search period continues through 1990. The search for bibliographic entries on this topic is not as simple as one might expect. The various and diverse labels used for the phenomena complicate the matter quite a bit. We therefore used several forms of electronic search, materials from bibliographies previously collected by the present authors, reference lists from articles on the topic, manual searches of a variety of indexes, mailings to active researchers in the field, plus a lot of "power browsing" through periodicals not usually surveyed by the usual psychological indexing and abstracting services. In addition to journal articles, this resulted in the discovery of several book chapters, as well as some papers either unpublished or in press. The final bibliography contains $\mathbf{4 4 5}$ entries and is about as complete as our stamina would allow.

A brief glance at the entries reveals some interesting features of research in this area. First, since the phenomenon is often referred to as a visual illusion, it is not surprising that, as is the case with most research in the area of the classical visual geometric illusions, theoretical approaches to subjective contours naturally fall into two distinct groups. The first is concerned with physiological or structural mechanisms that might explain the phenomena, while the second is more phenomenological in nature,

\section{Distribution of Theoretical Approaches To Subjective Contours}

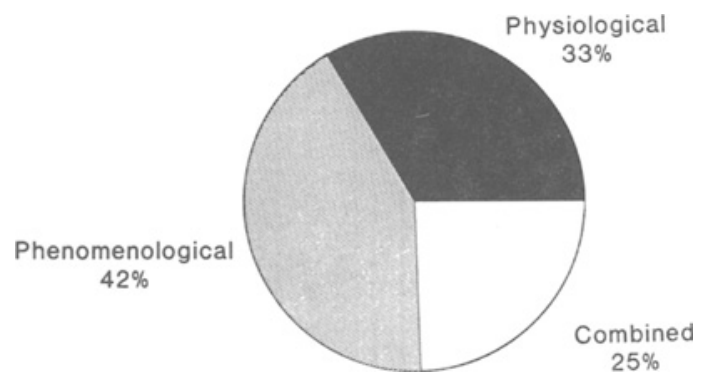

Figure 2. Distribution of theoretical approaches to subjective contours in the research literature.

\section{Distribution of Physiological Approaches To Subjective Contours}

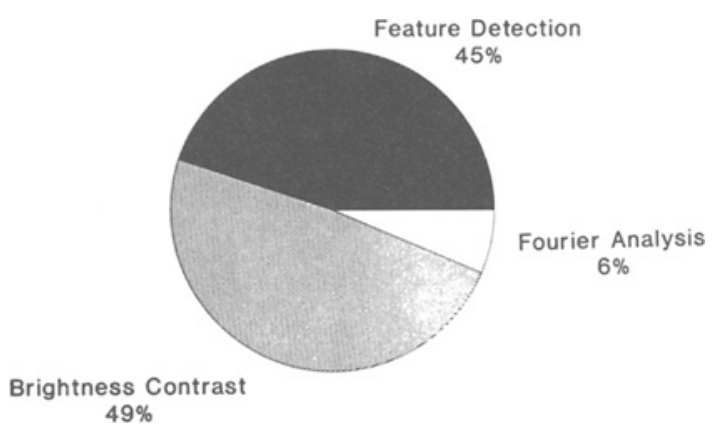

Figure 3. Distribution of the major physiological appraaches to subjective contour research (excluding color effects).

drawing its explanations from cognitive-judgmental and Gestalt-like processes. As can be seen in Figure 2, the phenomenological approach has tended to be a bit more popular than the physiological approach, and about 25\% of the literature has taken a combined or multicausal viewpoint, which permits the interaction of mechanisms from both levels.

Within the two approaches to subjective contours, certain themes have been consistent. When we analyze the publications that have presented an exclusively physiological orientation to the problem (see Figure 3), we find that nearly half have reported some form of lateral neural interactions, analogous to the lateral inhibitory processes on the retina that are used to explain brightness contrast, as the mechanism that produces subjective contours. In some instances, these interactions are moved a bit higher into the visual system, or left with their locus not clearly indicated, rather than with a clearly retinal locus. The second major physiological theme has invoked the action of various feature detectors in the cortex. Some of these are the traditional orientation-specific units found in V1 through V3, but other new and special units have been suggested, such as end-stop sensitive receptors or dipole triggered units, to explain the final perception of subjective lines and edges. Another form of treatment has explored the possibility of visual analogues to Fourier analysis. This approach reached its peak in the early 1980 s and has diminished in importance in the more recent literature.

The more cognitive and phenomenological approaches display a bit more diversity. If we ignore theories that have involved color or transparency as a component, we find that the most popular approaches were among the first to be promulgated. Coren's "implicit depth cue" theory is still the most frequently addressed in the literature, followed reasonably closely by Gregory's "object hypothesis," as can be seen in Figure 4. Kanizsa's own "amodal completion theory" is next in popularity. This last approach, which often contains strong elements analogous to the Gestalt interpretation of closure, seems to have encouraged a variety of different variants of Gestalt-like 


\section{Distribution of Phenomenological Theories of Subjective Contours}

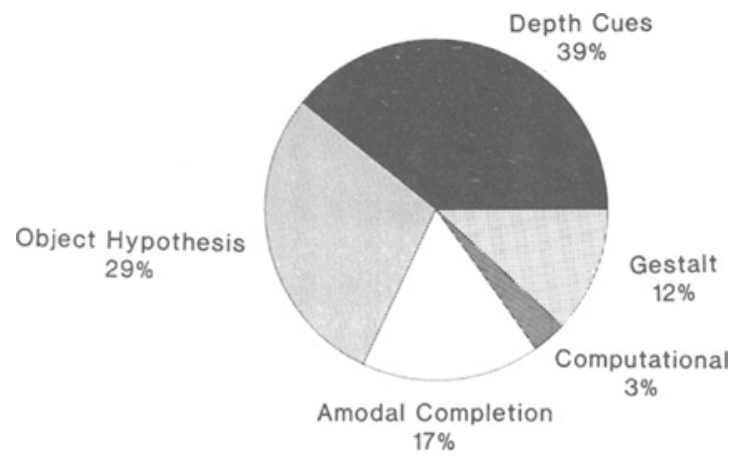

Figure 4. Distribution of the phenomenological and cognitive approaches to subjective contour research (excluding color and transparency).

\section{National Output of Studies of Subjective Contour}

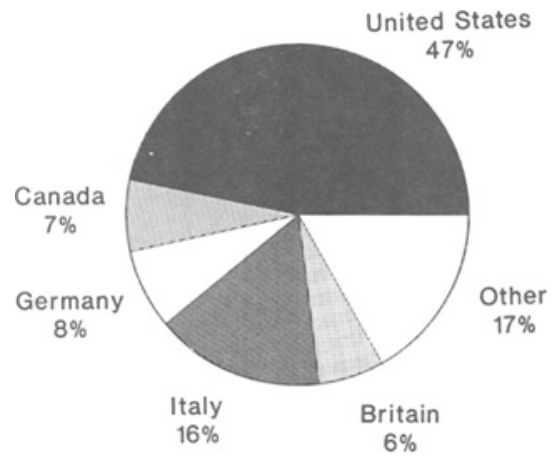

Figure 5. Output of publications on subjective contours by country of origin of the research (countries contributing less than 5\% not listed separately).

hypotheses that incorporate, in addition to closure, processes analogous to perceptual grouping, good continuation, figural goodness, and Prägnanz to explain the phenomena. In a small number of papers, computational theories of subjective contours have been attempted.

Finally, the international distribution of subjective contour publications also shows some historical hysteresis. Figure 5 shows the national origin of subjective contour publications for nations contributing $5 \%$ or more of the literature. Although the largest contribution to the literature comes from the United States, the second largest comes from Italy, which is presumably a direct result of Kanizsa's early influence in this area. Canada and Great Britain are also significant contributors. The publications from Germany are interesting in that they tend to focus almost exclusively on one class of subjective contour stimuli-namely, those that produce the diffuse bright- ness patterns often referred to as the Ehrenstein illusion and the closely related Hermann grid. This particular class of stimuli is not uniformly accepted as falling into the same class as the Kanizsa type of subjective contours, but they are included here for completeness.

The full bibliography that we collected is presented below. For items not in English, we have provided a translation of the title in square brackets. Each entry is followed with a code that indicates something about the content of the paper. We have chosen the codes to reflect the theoretical orientation of the particular items or to give some indication of the hypotheses tested. This added annotation is provided to help researchers gather materials that may fit within specific areas. Each code contains one or more numbers, defining our interpretation of the global issues and orientation found in that paper, with one or more letters after each number, defining specific hypotheses tested or discussed extensively. The following code categories are used:

1. Physiological theories, mechanisms or methodologies.

FD Feature detectors or higher level neural mechanisms.

C Contrast-like phenomena, including lateral inhibition and lower level lateral neural interactions.

F Physiological responses that mimic Fourier analysis.

O Other physiological mechanisms.

2. Cognitive and phenomenological theories and methodologies.

$\mathrm{OH}$ Object hypothesis theories similar to those of Gregory.

D Implicit or explicit depth-cue-based theories analogous to those of Coren.

A Amodal completion theories like those of Kanizsa.

G Gestalt hypotheses involving any Gestalt-like mechanism other than amodal completion.

AS Assimilation-based theories, similar to brightness assimilation.

C Computational theories of any form other than Fourier analyses.

DV Explicit developmental methodology or theory.

O Other cognitive and phenomenological approaches.

3. Miscellanea defined more by specific stimulus pattern or perceptual effects than by theoretical approach.

HG Studies focusing on the Hermann grid.

E Entries that concentrate on the Ehrenstein illusion.

NC The class of phenomena known as the neon color illusion, neon spreading effect, or color spreading effect.

IL Mostly attempts to use subjective contours in classical visual geometric illusions, or attempts to explore other illusory effects by using subjective contours as a tool.

$T$ Transparency effects.

O Other subjective contour entries that defy categorization according to the categories above.

Any bibliography is basically static; it becomes more and more dated moment by moment. We think that it is 
important to make this listing of the literature available to other researchers in a form that is useful for composing manuscripts, but that can be updated so that it can continue to grow. For this réason, we will provide a text version of the bibliography in PC DOS or Macintosh formats to any researcher who provides us with an appropriately formatted disk and a return mailer (see authors' note for the address).

\section{Subjective Contours 1900-1990: A Bibliography}

Abravanel, E. (1982). Perceiving subjective contours during early childhood. Journal of Experimental Child Psychology, 33, 280-287. 2OHGDV

BachmanN, T. (1978a). Cognitive contours: Overview and a preliminary theory. In Problems of communication and perception (Acta et Commentationes Universitatis Tartuensis No. 474: Studies in Psychology No. 7, pp. 31-59). Tartu, Estonia: Tartu State University. 2G Review

Bachmann, T. (1978b). Kognitivniye kontury: Primery i gipotezy [Cognitive contours: Examples and hypotheses]. In T. Vniite (Ed.), Ergonomika Issue 16: Research on cognitive and performance activity (pp. 151-167). Moscow. 2G Review

BACHMANN, T. (1979). Issledovaniye vospriyatiya sub'ektivnykh konturov metodom opredeleniya kontrastnoy chustvitel'nosti [Study of cognitive contours with the method of contrast sensitivity determination]. Vestnik Moskovskogo Universiteta: Seriya 14. Psikhologiya, 1, 21-29. ICF

Banks, W. P., * Coffin, S. (1974). Implicit depth cues do not create subjective contours. Psychological Review, 81, 265. 2DG

Barolo, E., Masini, R. (1980). Contributo sperimentale al problema dei margini quasi-percettivi [Experimental contribution to the problem of quasiperceptive contours]. In Reports from the Institute of Psychology (pp. 1-39). Milan: University of Milan, Medical Faculty. 2AG

BECKETT, P. A. (1981, May). Transversal angle effect in real-and subjective-contour Poggendorffigures. Paper presented at the meeting of the Midwestern Psychological Association, Detroit. 3IL

BECKETT, P. A. (1989). Illusion decrement and transfer of illusion decrement in real- and subjective-contour Poggendorff figures. Perception \& Psychophysics, 45, 550-556. 3IL

BecketT, P. A. (1990). Similar processing of real- and subjectivecontour Poggendorff figures by men and women. Perceptual \& Motor Skills, 70, 51-56. 3IL

Beckett, P. A., Hyrajt, S. (1988). Real and subjective contour Poggendorff illusions: No differences based on eye color. Perception, 17, 311-313. 3IL

Berbaum, K., Chung, C. S. (1981). Perceptive field size and a new version of the Hermann grid. Perception, 10, 85-89. 1FD3HG

Bertenthal, B. I., Campos, J. J., \& Haith, M. M. (1980). Development of visual organization: The perception of subjective contours. Child Development, 51, 1072-1080. 2OHDV

Bonafuto, P., Giannini, A. M., Bonaluto, M. (1991). Visual illusory productions with or without amodal completion. Perception, 20, 243-258. 2 GO

BozzI, P. (1975). Osservazioni su alcuni casi di trasparenza fenomenica realizzabili con figure a tratto [Observations on some cases of phenomenal transparency created by line-element patterns]. In G. B. Flores D'Arcais (Ed.), Studies in perception (pp. 88-110). Florence: Martello. 2AG3T

BraDLEY, D. R. (1982). Binocular rivalry of real vs. subjective contours. Perception \& Psychophysics, 32, 85-87. 1FD2D

BRADLEY, D. R. (1983). Nuove osservazioni sui margini soggettivi [New observations on subjective contours]. Giomale ltaliano di Psicologia, 10, 329-358. 2OHDG
BradLEY, D. [R.] (1986). Cognitive contours and perceptual organization. Perception \& Psychophysics, 39, 213. (Abstract) 2OHDG

Bradley, D. R. (1987). Cognitive contours and perceptual organization. In S. Petry \& G. E. Meyer (Eds.), The perception of illusory contours (pp. 201-212). New York/Berlin: SpringerVerlag. 2OHDG

Bradley, D. R., Dumais, S. T. (1975). Ambiguous cognitive contours. Nature, 257, 582-584. 2OHD

Bradley, D. R., Dumais, S. T. (1984). The effects of illumination level and retinal size on the depth stratification of subjective contour figures. Perception, 13, 155-164. 1FDC2D

Bradley, D. R., Dumais, S. T., Petry, H. M. (1976). Reply to Cavonius. Nature, 261, 77-78. 2OH

BradLEY, D. R., Hrrsch, R. G. (1987). Cognitive style and subjective contours. Unpublished manuscript. 2G

BRADley, D. R., LEE, K. (1982), Animated subjective contours. Perception \& Psychophysics, 32, 393-395. IFD2OHG

Bradley, D. R., MAtes, S. M. (1985). Perceptual organization and apparent brightness in subjective contour figures. Perception, 14, 645-653. 1C2OHG

Bradley, D. R., Pe Pennella, M. A. (1987). The effect of eye movements on the apparent strength of subjective contours. Unpublished manuscript. 2OHG

Bradley, D. R., \& PeTry, H. M. (1977). Organizational determinants of subjective contour: The subjective Necker cube. American Journal of Psychology, 90, 253-262. 2OHDG

BRADLEY, D. R., WOOD, L. C. (1987). The effects of rotation on the apparent shape of real and subjective contours. Unpublished manuscript. IFD2G

Brady, M., Grimson, W. E. L. (1981). The perception of subjective surfaces (Memo No. 666). Cambridge, MA: MIT Artificial Intelligence Laboratory. 1FD2GC

Brandeis, D. U., Jin, G. C., Lehmann, D., Mueller, R. U. (1985). Late EP components related to subjective contour perception and to attention. Electroencephalography \& Clinical Neurophysiology, 61, 58. 1FDO

Brandeis, D. U., Lehmann, D. (1989). Segments of eventrelated potential map series reveal landscape changes with visualattention and subjective contours. Electroencephalography \& Clinical Neurophysiology, 73, 507-519. 1FDO

Brandeis, D. U., LeHmanN, D., \& Mueller, R. U. (1985). Late EP negativity and perception of the Kanizsa triangle. Biological Psychiatry, 20, 192-193, 1FDO

Bravo, M., Blake, R., Morrison, S. (1988). Cats see subjective contours. Vision Research, 28, 861-865. 1FDF

Bressan, P. (1987). Subjective rarefaction in illusory figures: The inadequacy of apparent lightness as an explanation. Perception, 16, 461-466. 1C2D

Bressan, P., \& Vallortigara, G. (1986). Subjective contours can produce stereokinetic effects. Perception, 15, 409-412. 2OHDG

Bressan, P., VAllortigara, G. (1987). Stereokinesis with moving visual phantoms. Perception, 16, 73-78. 2OHDG

Brigner, W. L. (1982). Mathematical model for the filling-in of illusionary contour. Perceptual \& Motor Skills, 54, 815-820. 1FDC2C

Brigner, W. L., \& Gallagher, M. B. (1974). Subjective contour: Apparent depth or simultaneous brightness contrast? Perceptual \& Motor Skills, 38, 1047-1053. 1C2D

Brigner, W. L., \& Hammond, J. T. (1981). Role of brightness contrast and brightness contrast-reversal in illusory contour formation. Perceptual \& Motor Skills, 52, 415-424. 1C2D

Bross, M., \& Michelangeu, L. (1988). The role of inducer alignment and practice in the perception of subjective contours. Perception, 17, 391. 1FD2G

Brown, J. M. (1985). Phantom contour completion: A figure/ground approach. Unpublished doctoral dissertation, State University of New York at Buffalo. 1FD2G 
Brown, J. [M.] (1986). Phantom figures affect orientation discrimination performance. Perception \& Psychophysics, 39, 217. (Abstract) 1FD2G

BRown, J. M, WeissteIN, N. (1984). Moving visual phantoms: Evidence of figure/ground perception. Investigative Ophthalmology \& Visual Science, 25. (Abstract) 1FD2G

Brown, J. M., \& Weisstein, N. (1985a). Flickering phantoms: A figure/ground approach. In Proceedings and Abstracts of the Annual Meeting of the Eastern Psychological Society, 56, 38. 1FD2G

Brown, J. M., \& Weisstein, N. (1985b). Visual phantoms enhance target visibility: An illustration of the power of figural organization. Unpublished manuscript. 1FD2G

Brown, J. M., \& WeISsteIN, N. (1986). Depth information within phantom inducing regions can influence phantom visibility. In Proceedings and Abstracts of the Annual Meeting of the Eastern Psychological Association, 57, 63. 1FD2DG

Brown, J. M., \& WeISsTeIN, N. (1988). A phantom context effect: Visual phantoms enhance target visibility. Perception \& Psychophysics, 43, 53-56. 1FD2OHG

Brown, J. M., Weisstein, N., \& Genter, C. R., II. (1980). Perceiving underlying form or object in a fragmented "street" figure strengthens moving phantom contours. Bulletin of the Psychonomic Society, 16, 151. (Abstract) 2G

Brown, J. M., Weisstein, N., \& Genter, C. R., II. (1981). Fragmented "street" figures can produce flickering phantom contours, moving phantom contours, and a phantom motion aftereffect. In vestigative Ophthalmology \& Visual Science, 20. (Abstract) 2G3IL

Bruno, N. (1989). Two kinds of occlusion events and the shape of illusory figures. Contributi di Psicologia, 5, 3-19. 2OHD

BRUno, N., \& Bertamini, M. (1990). Identifying contours from occlusion events. Perception \& Psychophysics, 48 331-342. 2OHD

Bruno, N., Gerbino, W. (1986). An information processing analysis of illusory figures. Perception \& Psychophysics, 39, 212213. (Abstract) 2OHGC

Bruno, N., Geraino, W. (1987). Amodal completion and illusory figures: An information-processing analysis. In S. Petry \& G. E. Meyer (Eds.), The perception of illusory contours (pp. 220223). New York/Berlin: Springer-Verlag. 2OHGC

BRUno, N., GerBino, W. (1991). Mlusory figures based on local kinematics. Perception, 20, 259-274. 2G

Brussel, E. M., Stober, S. R., Bodinger, D. M. (1977). Sensory information and subjective contour. American Journal of Psychology, 90, 145-156. 1FDC

Cavanagh, P. (1985, November). Subjective contours signaled by luminance, vetoed by motion or depth. Paper presented at the meeting of the Psychonomic Society, Boston. IFDC2D

Cavonius, C. R. (1976). Ambiguous cognitive contours. Nature, 261, 77-78. 2OHDG

Celu, G., ANGeuni, P., \& Censi, L. (1987). Contributi all'etologia dell'ape in serra: 4 . Su di un caso di condizionamento inverso e di ragionamento astratto in Apis mellifera L. (Hymenoptera apidae) [Contribution to the ethology of the honeybee: 4 . On a case of inverse conditioning and abstract reasoning in Apis mellifera L.]. Bollettino dell'Istituto di Entomologia "Guido Grandi" dell'Universita di Bologna, 42, 131-137. 20

Chung, C., \&ARK, M. (1985). A pulse model for simultaneous brightness contrast in the Hermann grid. Korean Journal of Psychology, 5, 2-7. 1C3HG

Cohen, M. A., Grasseerg, S. (1984). Neural dynamics of brightness perception: Features, boundaries, diffusion, and resonance. Perception \& Psychophysics, 36, 428-456. 1FDCO2C

Corbetta, M., Antonini, A., Berlucchi, G., Aglioti, S. (1989). Texture discrimination and illusory contour perception in normal and decorticated cats. Pflugers Archiv-European Journal of Physiology, 414, 61. 1FDO

Coren, S. (1972). Subjective contours and apparent depth. Psychological Review, 79, 359-367. 2OHDG

Coren, S. (1974). Reply to Banks and Coffin. Psychological Review, 81, 266. 2D

Coren, S. (1983). When "filling in" fails. Behavioral \& Brain Sciences, 6, 661-662. 1FDC2AS

CoREN, S. (1991). Retinal mechanisms in the perception of subjective contours: The contribution of lateral inhibition. Perception, 20, 181-191. 1C

Coren, S., Girgus, J. S. (1978). Seeing is deceiving: The psychology of visual illusions. Hillsdale, NJ: Erlbaum. 2D Review

Coren, S., Porac, C. (1983). Subjective contours and apparent depth: A direct test. Perception \& Psychophysics, 33, 197-200. 2D

Coren, S., Porac, C., Theodor, L. H. (1986a). The effects of perceptual set on the shape and apparent depth of subjective contours. Perception \& Psychophysics, 39, 327-333. 2OHO

Coren, S., Porac, C., \& Theodor, L. H. (1986b). Set and subjective contour. Perception \& Psychophysics, 39, 212. (Abstract) $2 \mathrm{OHO}$

Coren, S., Porac, C., Theodor, L. H. (1987). Set and subjective contour. In S. Petry \& G. E. Meyer (Eds.), The perception of illusory contours (pp. 237-245). New York/Berlin: SpringerVerlag. 2OHO

Coren, S., \& PURGhÉ, F. (1990). Amodal completion, depth perception and the formation of subjective contours. Perception, 19, 411. 2DAG

Coren, S., \& Theodor, L. H. (1975). Subjective contour: The inadequacy of brightness contrast as an explanation. Bulletin of the Psychonomic Society, 6, 87-89. 1C

COREN, S., \& ThEODOR, L. H. (1977). Neural interactions and subjective contours. Perception, 6, 107-111. IC

DAFFNER, R. H. (1989). Visual illusions in the interpretation of the radiographic image. Current Problems in Diagnostic Radiology, $18,62-87.30$

Davis, S. J., \& Jernigan, M. E. (1982). Ambiguous edge detection leads to subjective contours. Perception \& Psychophysics, 31, 93-94. 1FD2OH

DAY, R. H. (1983). Neon color spreading, partially delineated borders, and the formation of illusory contours. Perception \& Psychophysics, 34, 488-490. 2GAS3NC

DAY, R. H. (1986a). Enhancernent of edges by contrast, depth and figure: The origin of illusory contours. In J. D. Pettigrew, K. J. Sanderson, \& W. R. Levick (Eds.), Visual neurosciences. Cambridge: Cambridge University Press. 1FDC2OHD

DAY, R. H. (1986b). Keynote presentation: Some data, some problems, some speculations. Perception \& Psychophysics, 39, 211. (Abstract) 1C2DGOH

DAY, R. H. (1987). Cues for edge and the origin of illusory contours: An alternative approach. In S. Petry \& G. E. Meyer (Eds.), The perception of illusory contours (pp. 53-61). New York/Berlin: Springer-Verlag. 1C2OHDG

DAY, R. H., Dickinson, R. G., a JoRY, M. K. (1977). The Poggendorff illusion with subjective contours. Quarterly Journal of Experimental Psychology, 29, 219-226. 3IL

DAY, R. H., JORY, M. K. (1978). Subjective contours, visual acuity, and line contrast. In J. C. Armington, J. E. Krauskopf, \& B. Wooten (Eds.), Visual psychophysics and physiology (pp. 331-349). New York: Academic Press. 1FDC

DAY, R. H., JoRY, M. K. (1980). A note on a second stage in the formation of illusory contours. Perception \& Psychophysics, 27, 89-91. $2 \mathrm{OH}$

DAy, R. H., KASPERCZYK, R. T. (1983a). Amodal completion as a basis for illusory contours. Perception \& Psychophysics, 33, 355-364. 1C2OHAAS 
DAY, R. H., \& KASPERCZYK, R. T. (1983b). Ilusory contours in line patterns with apparent depth due to either perspective or overlay. Perception, 12, 485-490. 2DG

De WeErt, C. M. M. (1979). Colour contours and stereopsis. Vision Research, 19, 555-564. 1FD2D

De WeERT, C. M. M. (1983). The role of colours in the formation of subjective contours. Psychological Research, 45, 117-134. IC

DE WEERT, C. M. [M.] (1986). Contour sharpness and perceptual transparency. Perception \& Psychophysics, 39, 220. (Abstract) 1FDC3T

De Weert, C. M. M., Van KruYsbergen, N. A. W. H. (1987). Subjective contour strength and perceptual superimposition: Transparency as a special case. In S. Petry \& G. E. Meyer (Eds.), The perception of illusory contours (pp. 165-170). New York/ Berlin: Springer-Verlag. 1FDC3T

De Weert, P., Vandenbussche, E., De Bruyn, B., Orban, G. A. (1990). Illusory contour orientation discrimination in the cat. $B e$ havioural Brain Research, 39, 1-17. 1FDC30

DOUGHerTy, T. J. (1990). Contour: A hypermedia environment for teaching about subjective contours and other visual illusions. $B e$ havior Research Methods, Instruments, \& Computers, 22, 223-227. 20

Dresp, B., Bonnet, C. (in press). Psychophysical evidence for low processing in illusory contours and surfaces in the Kanizsa square. Vision Research. ICF

Dumais, S. T., Bradley, D. R. (1976). The effects of illumination level and retinal size on the apparent strength of subjective contours. Perception \& Psychophysics, 19, 339-345. 1FDC2OH

EHRENSTEIN, W. (1941). Über Abwandlungen der L. Hermannschen Helligkeits-Erscheinung. Zeitschrift fur Psychologie, 150, 83-91. [Also published as modifications of the brightness phenomenon of L. Hermann, trans. A. Hogg, in S. Petry \& G. E. Meyer (Eds.), The perception of illusory contours (pp. 35-39). New York Berlin: Springer-Verlag, 1987.] 1C3HGE

EHRENSTEIN, W. (1942). Beitrage zur Ganzheitspsychologischen Wamehmungslehre [Contributions to a holistic theory in perception]. Leipzig: J. A. Barth. 1C3HGE

EhrensteIn, W. (1954). Probleme der Ganzheitspsychologischen Wahrnemungslehre [Problems of a holistic theory in perception] (3rd ed.). Leipzig: J. A. Barth. 1C3HGE

Ejma, Y., Redies, C., Takahashi, S., * AkIta, M. M. (1984). The neon color effect in the Ehrenstein pattern: Dependence on wavelength and illuminance. Vision Research, 24, 1719-1726. 1C2AS3NC

EJIMA, Y., \& TAKAhashi, S. (1988). Illusory contours induced by isoluminant chromatic patterns. Vision Research, 28, 1367-1377. $1 \mathrm{C}$

FARNÉ, M. (1968). Alcune osservazioni con linee virtuali e margini quasi-percettivi [Some observations on virtual lines and quasiperceptive contours]. Bollettino della Societd Italiana di Biologia Sperimentale, 44, 1613-1616. 2AG

FrASER, A. S. (1983a). Depth perception and subjective contours. Perceptual \& Motor Skills, 56, 847-850. 2D

Fraser, A. S. (1983b). Ehrenstein variations. Perception, 12, 143-147. 2O3E

Fraser, A. S., Wilcox, K., \& Storgion, S. (1982). The fillingin illusion and moving visual phantoms. Perceptual \& Motor Skills, 54, 343-355. 1C2G

Frisby, J. P., \& Clatworthy, J. L. (1975). Illusory contours: Curious cases of simultaneous brightness contrast. Perception, 4, 349-357. 1C2A

FuLD, K., \& O'DONNELL, K. (1984). Brightness matching and scaling of the Ehrenstein illusion. In L. Spillmann \& B. R. Wooten (Eds.), Sensory experience, adaptation, and perception (pp. 461469). Hillsdale, NJ: Erlbaum. 1C3E

Gellatly, A. R. H. (1980). Perception of an illusory triangle with masked inducing figure. Perception, 9, 599-602. 1FDO2O
Gellatly, A. R. H. (1982). Perceptual learning of illusory contours and color. Perception, 11, 655-661. 1O2OHO

Gellatly, A. R. H., Bishop, M. J. (1986). A skills analysis of the perception of illusory contours. Perception \& Psychophysics, 39, 221. (Abstract) 102OHGO

Gellatly, A. R. H., BishoP, M. J. (1987). The perception of illusory contours: A skills analysis. In S. Petry \& G. E. Meyer (Eds.), The perception of illusory contours (pp. 262-267). New York/Berlin: Springer-Verlag. 102OHGO

Genter, C. R., \& Weisstein, N. (1981). Flickering phantoms: A motion illusion without motion. Vision Research, 21, 963-966. 1FD

GerBino, W. (1989). Form categorization and amodal completion. Acta Psychologica, 72, 295-300. 2OHA

Gerbino, W., \& Kanzsa, G. (1986). Can we see constructs? Thirty years of illusory figures. Perception \& Psychophysics, 39, 220221. (Abstract) 2OHA

Gerbino, W., \& KanizsA, G. (1987). Can we see constructs? In S. Petry \& G. E. Meyer (Eds.), The perception of illusory contours (pp. 246-252). New York/Berlin: Springer-Verlag. 2OHA

GHIM, H. (1990). Evidence for perceptual organization in infants: Perception of subjective contours by young infants. Infant Behavior \& Development, 13, 221-248. 2DV

Giannini, A. M., \&onaruto, P. (1987). Studi sulla visione e ricerca pittorica in Gaetano Kanizsa [Studies on vision and pictorial research in Gaetano Kanizsa's work]. Attualità di Psicologia, 2, 89-96. 2AGO

GiBSON, J. J. (1950). The perception of the visual world. Boston: Houghton Mifflin. Review

GiLdEN, D. L., MAcDonald, K. E., \& LASAGA, M. I. (1988). Masking with minimal contours: Selective inhibition with low spatial frequencies. Perception \& Psychophysics, 44, 127-132. 1FDF

GillaM, B. (1986). The aggregation of collinear lines. Perception \& Psychophysics, 39, 220. (Abstract) 2G

GiLlAM, B. (1987). Perceptual grouping and subjective contours. In S. Petry \& G. E. Meyer (Eds.), The perception of illusory contours (pp. 268-273). New York/Berlin: Springer-Verlag. 2G GinsBuRG, A. P. (1975). Is the illusory triangle physical or imaginary? Nature, 257, 219-220. 1F

GinsBuRG, A. P. (1986). The relationship between spatial filtering and subjective contours. Perception \& Psychophysics, 39, 215. (Abstract) 1F

GINSBURG, A. P. (1987). The relationship between spatial filtering and subjective contours. In S. Petry \& G. E. Meyer (Eds.), The perception of illusory contours (pp. 126-130). New York/Berlin: Springer-Verlag. IF

Goldstein, M. B., \& Weintraub, D. J. (1972). The parallel-less Poggendorff: Virtual contours put the illusion down but not out. Perception \& Psychophysics, 11, 353-355. 2O3IL

Gregory, R. L. (1972). Cognitive contours. Nature, 238, 51-52. $2 \mathrm{OH}$

GREGORY, R. L. (1977). Vision with isoluminant color contrast: 1. A projection technique and observation. Perception, 6, 113-119. 1FDC

GREGORY, R. [L.] (1986). Illusory surfaces as perceptual postulates. Perception \& Psychophysics, 39, 220. (Abstract) 1FD2OH GREGORY, R. L. (1987). Illusory contours and occluding surfaces. In S. Petry \& G. E. Meyer (Eds.), The perception of illusory contours (pp. 81-89). New York/Berlin: Springer-Verlag. 1FD2OH Gregory, R. L., * HARRIS, J. P. (1974). Illusory contours and stereo depth. Perception \& Psychophysics, 15, 411-416. 2D

Grossberg, S. (1987a). Cortical dynamics of three-dimensional form, color, and brightness perception: I. Monocular theory. Perception \& Psychophysics, 41, 87-116. 1FDCFO

GrossberG, S. (1987b). Cortical dynamics of three-dimensional form, color, and brightness perception: II. Binocular theory. Perception \& Psychophysics, 41, 117-158. 1FDCFO 
GrossberG, S. (1990). Neural facades: Visual representations of static and moving form-and-color-and-depth. Mind \& Language, 5, 411-456. 1FDCFO.

Grossberg, S., Mingolla, E. (1985a). Neural dynamics of form perception: Boundary completion, illusory figures, and neon color spreading. Psychological Review, 92, 173-211. 1FDCFO3NC

Grossberg, S., \& Mingolla, E. (1985b). Neural dynamics of perceptual grouping: Textures, boundaries, and emergent segmentations. Perception \& Psychophysics, 38, 141-171. 1FDCFO

Grossberg, S., \& Mingolla, E. (1986a). Computer simulation of neural networks for perceptual psychology. Behavior Research Methods, Instruments, \& Computers, 18, 601-607. IFDO3O

Grossberg, S., \&ingolla, E. (1986b). Neural dynamics of boundary completion and textural grouping: Emergent segmentations and contour visibility. Perception \& Psychophysics, 39, 215. (Abstract) 1FDCFO2G

Grossberg, S., \& Mingolla, E. (1987a). Neural dynamics of surface perception: Boundary webs, illuminants, and shape from shading. Computer Vision, Graphics, \& Image Processing, 37, 116-165, 1FDCFO2D

Grossberg, S., Mingolla, E. (1987b). The role of illusory contours in visual segmentation. In S. Petry \& G. E. Meyer (Eds.), The perception of illusory contours (pp. 116-125). New York Berlin: Springer-Verlag. 1FDCFO

Grossberg, S., Mingolla, E., \& Todorovic, D. (1989). A neural network architecture for preattentive vision. IEEE Transactions on Biomedical Engineering, 36, 65-84. 1FDCFO

HALPERN, D. F. (1980). The determinants of subjective contour perception. Dissertation Abstracts International, 40, 3995. 1C2OHD

HALPERN, D. F. (1981). The determinants of illusory-contours perception. Perception, 10, 199-213. 1C2OHD

HALPERN, D. F. (1987). The functional equivalence of objective and illusory brightness enhancement. In S. Petry \& G. E. Meyer (Eds.), The perception of illusory contours (pp. 171-175). New York/Berlin: Springer-Verlag. $1 \mathrm{C} 2 \mathrm{O}$

HalPERN, D. F., \& SAlzman, B. (1983). The multiple determination of illusory contours: 1. A review. Perception, 12, 281-291. 1FDC2DG

Halpern, D. F., Salzman, B., Harrison, W., \& Widaman, K. (1983). The multiple determination of illusory contours: 2 . An empirical investigation. Perception, 12, 293-303. 1FDC2DG

Halpern, D. F., Salzman, B., \& Youngworth, C. (1986). The functional equivalence of illusory and objective brightness enhancement. Perception \& Psychophysics, 39, 220. (Abstract) 1C

HaLPERN, D. F., \& WARM, J. S. (1980). The disappearance of real and subjective contours. Perception \& Psychophysics, 28, 229-235. 1FD2O

HALPERN, D. F., W WARM, J. S. (1984). The disappearance of dichoptically presented real and subjeetive contours. Bulletin of the Psychonomic Society, 22, 433-436. 1FD2G

HamadA, J. (1982). The contour enhancement effects produced by darkening effects. In H. G. Geissler \& P. Petzold (Eds.), Psychophysical judgment and the process of perception (pp. 132-139). Amsterdam: North-Holland. $1 \mathrm{CO}$

HamadA, J. (1987). Overall brightness decrease observed in the Ehrenstein illusion induced for both contrast polarities. Perception \& Psychophysics, 41, 67-72. 1FDC

HAMSHER, K. D. (1978). Stereopsis and the perception of anomalous contours. Neuropsychologia, 16, 453-459. 2D

HaRRINGToN, T. L., \& QUON, D. (1989). A method of stereoptically simulating manifolds of three-dimensional objects using only a single display pattern: A shape-depth-texture invariance. Perceptual \& Motor Skills, 68, 1163-1175. 1FDO

HARRIS, J. B., GREGory, R. L. (1973). Fusion and rivalry of illusory contours. Perception, 2, 235-247. 1FD2D

Hartmann, G. W. (1935). Gestalt psychology: A survey of facts and principles. New York: Ronald Press. Review
HELMHOLTZ, H. L. F. von (1867). Handbuch der physiologischen Optik. Leipzig: Voss. [Also published as Helmholtz's treatise on physiological optics, trans. J. P. C. Southall. New York: Optical Society of America, 1924-1925. Rpt. New York: Dover, 1962.] Figures, passing mention.

Hermann, L. (1870). Eine Erscheinung des simultanen Contrast [An effect of simultaneous contrast]. Pfilger Archiv gesamte Physiologie, 3, 13-15. 1C3HG

Hershberger, W., Stallard, S. (1984). Contrast variability lightens subjective figures. Perception \& Psychophysics, 36, 92-94. 1FDC

HiNe, T. (1987). Subjective contours produced purely by dynamic occlusion of sparse-points array. Bulletin of the Psychonomic Society, 25, 182-184. 2OHDG

Imbasciati, A., PURGhÉ, F. (1982). Rilievi sperimentali sulle dimensioni apparenti di alcune superfici anomale [Measurements on the apparent size of some anomalous surfaces]. In $\mathbf{M}$. CesaBianchi (Ed.), Ricerca di laboratorio e intervento nella societd: Orientamenti e prospettive della psicologia in Italia (pp. 121136). Milan: Unicopli. 2A

IshigUCHI, A. (1987). Illusory gray spots and diagonal lines on the Hermann grid. Japanese Psychological Research, 29, 112-119. ICF

JORY, M. K. (1986). Increment thresholds in illusory contour line patterns. Perception \& Psychophysics, 39, 218. (Abstract) 1FDC3E

JORY, M. K. (1987). Increment threshold in illusory contour line pattern. In S. Petry \& G. E. Meyer (Eds.), The perception of illusory contours (pp. 183-189). New York/Berlin: SpringerVerlag. 1FDC3E

JORY, M. K., \& DAY, R. H. (1979). The relationship between brightness contrast and illusory contours. Perception, 8, 3-9. IC

Julesz, B., \& FrISBY, J. P. (1975). Some new subjective contours in random-line stereograms. Perception, 4, 145-150. 1FDO

JUNG, R. (1973). Brightness induction by linear pattems and border cues to brightness. In R. Jung (Ed.), Handbook of sensory physiology (pp. 53-65). Berlin: Springer-Verlag. 1FDC3E

KANIzSA, G. (1954). Linee virtuali e margini fenomenici in assenza di discontinuità di stimolazione [Virtual lines and phenomenal contours in the absence of stimulus discontinuity]. In Atti X Convegno degli Psicologi Italiani (pp. 127-131). Milan. 2A

KANIZSA, G. (1955). Margini quasi-percettivi in campi con stimolazione omogenea. Rivista di Psicologia, 49, 7-30. [Also published as Quasiperceptual margins in homogeneously stimulated fields, trans. W. Gerbino, in S. Petry \& G. E. Meyer (Eds.), The perception of illusory contours (pp. 40-49). New York/Berlin: Springer-Verlag, 1987.] 2A

KANIZsA, G. (1970). Amodale Ergänzungen und Erwartungsfehler des Gestalt-psychologen [Amodal completion and the errors of expectation of the Gestalt psychologist]. Psychologische Forschung, 33, 325-344. 2AG

KanizsA, G. (1974). Contours without gradients or cognitive contours? Italian Journal of Psychology, 1, 107-123. 2OHDA

KANIZSA, G. (1975). The role of regularity in perceptual organization. In G. B. Flores D'Arcais (Ed.), Studies in perception. Milan: Martello. 2AG

KanizsA, G. (1976). Subjective contours. Scientific American, 234, 48-52. 2OHDA

KAnizsA, G. (1980). Grammatica del vedere. Bologna: Il Mulino. [Also published as Organization in vision. New York: Praeger, 1979.] 2OHDAG

Kanizsa, G., MASINI, R. (1988). Margini anomali netti e sfumati in condizioni stereocinetiche [Sharp-edged and diffuse anomalous contours in stereokinetic perception]. In Rapporto Tecnico Istituto di Psicologia (pp. 1-15). Milan: University of Milan, Medical Faculty. 2DA

Kanizsa, G., Masini, R., \& Perussia, F. (1981). Margini anomali netti e sfumati [Sharp-edged and diffuse anomalous contours]. 
In Reports from the Institute of Psychology (pp. 1-20). Trieste: University of Trieste. $2 A$

Kanizsa, G., Masini, R., \& Perussia, F. (1982). Differenze funzionali tra margini anomali nettire margini anomali sfumati [Functional differences between sharp-edged and diffuse anomalous contours]. In Reports from the Institute of Psychology (pp. 1-14). Trieste: University of Trieste. 2A

Kellman, P. J., \& Cohen, M. H. (1984). Kinetic subjective contours. Perception \& Psychophysics, 35, 237-244. IFD2OH

Kellman, P. J., \& Loukides, M. [G.] (1986a). Approaching the edge: An object perception view of static and kinetic subjective contours. Perception \& Psychophysics, 39, 216-217. (Abstract) 1FD2OH

Kellman, P. J., \& Loukides, M. [G.] (1986b). Configuration and brightness as causal factors in subjective contours: Two direct tests. Perception \& Psychophysics, 39, 212. (Abstract) 1FD2OH

Kellman, P. J., \& Loukides, M. G. (1987). An object perception approach to static and kinetic subjective contours. In S. Petry \& G. E. Meyer (Eds.), The perception of illusory contours (pp. 151-164). New York/Berlin: Springer-Verlag. 1FD2OH

Kellman, P. J., \& SHIPLeY, T. F. (1991). A theory of visual interpolation in object perception. Cognitive Psychology, 23, 141-221. 2OHDAG

KenNedy, J. M. (1975). Depth of an edge, coplanarity, slant depth, change in direction and change in brightness in the production of subjective contours. Italian Journal of Psychology, 2, 107-123. $1 \mathrm{C} 2 \mathrm{OHD}$

KENNEDY, J. M. (1976a). Attention, brightness and the constructive eye. In M. Henle (Ed.), Vision and artifact (pp. 33-48). New York: Springer. 2OHDG

KENNEDY, J. M. (1976b). Sun figure: An illusory diffuse contour resulting from an arrangement of dots. Perception, 5, 479-481. 1FD

KENNEDY, J. M. (1978a). Illusory contours and the ends of lines. Perception, 7, 605-607. 1FDC

KENNEDY, J. M. (1978b). Illusory contours not due to completion. Perception, 7, 187-189. 1FD2AD

KENNEDY, J. M. (1979). Subjective contours, contrast, and assimilation. In C. F. Nodine \& D. F. Fisher (Eds.), Perception and pictorial representation (pp. 167-195). New York: Praeger. 1FDC2OHDA

KENNEDY, J. M. (1981). Ilusory brightness and the ends of petals: Change in brightness without aid of stratification or assimilation effects. Perception, 10, 583-585. 1FDC2DAS

KENNEDY, J. M. (1986). Epistemology of subjective contours. Perception \& Psychophysics, 39, 214. (Abstract) 1FD2OHAG

KENNEDY, J. M. (1987). Lo, perception abhors not a contradiction. In S. Petry \& G. E. Meyer (Eds.), The perception of illusory contours (pp. 253-261). New York/Berlin: SpringerVerlag. 1FD2OHAG

KenNedY, J. M. (1988). Line endings and subjective contours. Spatial Vision, 3, 151-158. 1FDC

Kennedy, J. M., Chattaway, L. D. (1975). Subjective contours; binocular and movement phenomena. Italian Journal of Psychol$o g y, 2,353-367$. 1FD2DA

KENNEDY, J. M., \& LEe, H. (1976). A figure-density hypothesis and illusory contours brightness. Perception, 5, 387-392. 1FDC2OHG

KENNEDY, J. M., \& WARE, C. (1978). Illusory contours can arise in dot figures. Perception, 7, 191-194.' 1FDC2OH

KLYMENKo, V. (1984). The spatio-temporal determinants of the motion-induced contour (Doctoral dissertation, University of Buffalo, NY, 1984). Dissertation Abstracts International, 45, 704. 1FD

KLYMENKo, V. (in press). The resonance theory of kinetic shape perception: Constraints on perceiving spatial structure. In Proceedings of the First Conference on Visualization in Biomedical Computing. 1FD
KLYMenKo, V., \& Weisstein, N. (1981). The motion-induced contour. Perception, 10, 627-636. IFD

KLymenko, V., \& Weisstein, N. (1983). The edge of an event: Invariants of a moving illusory contour. Perception \& Psychophysics, 34, 140-148. 1FD2G

KLyMENKo, V., \& Weisstein, N. (1984). The razor's edge: A dichotomy between monohedral and dihedral edge perception. Vision Research, 24, 995-1002. 1FD2DG

KLYMENKo, V., Weisstein, N. (1986). Structure and motion: Illusory projective transformations. Perception \& Psychophysics, 39, 217. (Abstract) 1FD2DG

Klymenko, V., \& Weisstein, N. (1987). The resonance theory of kinetic shape perception and the motion-induced contour. In S. Petry \& G. E. Meyer (Eds.), The perception of illusory contours (pp. 143-148). New York/Berlin: Springer-Verlag. 1FD2DG Klymenko, V., Weisstein, N., \& Ralston, J. V. (1987). Ilusory contours, projective transformations and kinetic shape perception. Acta Psychologica, 64, 229-243. 1FD2DG

KofFKA, K. (1935). Principles of Gestalt psychology. New York: Harcourt Brace. Review

Kozaki, T., Nakano, Y., \& Yoshizawa, Y. (1987). A kind of phenomenal transparency or amodal perception? In Fourth International Conference on Event Perception and Action (pp. 112). Trieste. (Abstract) 2AS3T

LANDAUER, A. A. (1978). Subjective states and the perception of subjective contours. In J. P. Sutcliff (Ed.), Conceptual analysis and method in psychology: Essays in honour of W. M. ONeil. Sydney: University Press. $10 \mathrm{HO}$

Lavin, E., Costall, A. (1978). Detection thresholds of the Hermann grid illusion. Vision Research, 18, 1061-1062. IC3HG

Lawson, R. B., Cowan, E., Gibes, T. D., \& Witmore, C. G. (1974). Stereoscopic enhancement and erasure of subjective contours. Joumal of Experimental Psychology, 103, 1142-1146. 2D

LAwson, R. B., GuLICK, W. L. (1967). Stereopsis and anomalous contours. Vision Research, 7, 271-297. 1O2D

LAwson, R. B., MounT, D. C. (1967). Minimum condition for stereopsis and anomalous contours. Science, 158, 804-806. 1O2D

Lawson, R. B., Pandina, R. J. (1969). Effects of matrix elements on stereopsis and anomalous contours. Journal of Experimental Psychology, 81, 322-325. 102D

Levine, J., SpillmanN, L., Wolf, E. (1980). Saturation enhancement in colored Hermann grids varying only in chroma. Vision Research, 20, 307-313. 1C

Levy, M. M., LAwson, R. B. (1969). Stereopsis and anomalous contours from fragmented matrix stereograms. Psychological Record, 19, 305-311. 102D

Livingstone, M., \&ubel, D. (1987). Psychophysical evidence for separate channels for the perception of form, color, movement and depth. Journal of Neuroscience, 7, 3461-3468. 1FDO2DAS

Livingstone, M., \& HuBEL, D. (1988). Segregation of form, color, movement, and depth: Anatomy, physiology, and perception. Science, 240, 740-749. 1FDO2DAS

Luccio, R., EDILE, A. L. (1981). Il completamento amodale di superfici anomale [Amodal completion of anomalous surfaces]. Giornale Italiano di Psicologia, 8, 141-147. 2A

Luccio, R., VARDABasso, F. (1989). Completamento amodale, superfici anomale e percezione di numerosita [Amodal completion, anomalous surfaces and the perception of numerosity]. Giomale Italiano di Psicologia, 16, 513-519. 2A3IL

MacKAY, D. M. (1981). Texture-contrast analogues of the Spillmann-Redies effect. Perception, 10, 417-420. 1FDO2AS3ENC MAguire, W. [M.] (1986). Phantom contours and brightness induction effects with flickering gratings. Perception \& Psychophysics, 39, 217. (Abstract) 1FDC2DG 
Maguire, W. M., Blattberg, K. (1986). Effects of contrast of occluder and flicker frequency on displays which produce phantom contours. In Proceedings of the Annual Meeting of the Eastern Psychological Association, 57, 62. (Abstract) 1CFO

Maguire, W. M., \& Brown, J. M. (1987). The current state of research into visual phantoms. In S. Petry \& G. E. Meyer (Eds.), The perception of illusory contours (pp. 213-219). New York/ Berlin: Springer-Verlag. 1FDC2DG

MASINI, R. (1980). Contributo sperimentale al problema dell'espansione fenomenica in funzione del completamento amodale con superfici anomale [Experimental contribution to the problem of phenomenal expansion as a function of amodal completion with anomalous surfaces]. In Reports from the Institute of Psychology (pp. 19-28). Milan: University of Milan, Medical Faculty. 2A

MAsinI, R. (1984). La contrazione fenomenica della illusione di Müller-Lyer in funzione del completamento amodale con superfici anomale [Phenomenal contraction of the Müller-Lyer illusion as a function of amodal completion with anomalous surfaces]. In G. Kanizsa (Ed.), Fenomenologia sperimentale della visione (pp. 195-203). Milan. 2A3IL

Masini, R., \& Perussia, F. (1980a). Considerazioni empiriche su alcuni effetti funzionali di superfici anomale [Empirical arguments on some functional effects due to anomalous surfaces]. In Reports from the Institute of Psychology (pp. 39-46). Milan: University of Milan, Medical Faculty. 2A

Masini, R., \& Perussia, F. (1980b). Contributo sperimentale al problema della contrazione fenomenica di un'illusione otticogeometrica in funzione del completamento amodale con superfici anomale [Experimental contribution to the problem of phenomenal shrinkage of an optical geometrical illusion as a function of amodal completion with anomalous surfaces]. In Reports from the Institute of Psychology (pp. 7-18). Milan: University of Milan, Medical Faculty. 2A3IL

MAsinI, R., \& PERUSSIA, F. (1983). Margini anomali netti e margini anomali sfumati: Un'analisi multivariata [Sharp-edged and diffuse anomalous contours: A multivariate analysis]. In Reports from the Institute of Psychology (pp. 1-21). Milan: University of Milan, Medical Faculty. 2D

MATHER, G. (1988). Temporal properties of apparent motion in subjective figures. Perception, 17, 729-736. 2OHG

MATHER, G. (1989). The role of subjective contours in capture of stereopsis. Vision Research, 29, 143-146. 2OHDG

Matthaei, R. (1929). Das Gestaltproblem. München. Review

MCCArTer, A. (1979). Chromatic induction effects in the Hermann grid illusion. Perception, 8, 105-114. 1C

MEYER, G. E. (1986). Interactions of subjective contours with the Ponzo, Müller-Lyer, and vertical-horizontal illusions. Bulletin of the Psychonomic Society, 24, 39-40. 203IL

MEYer, G. E., \& ChOW, Y. M. (1984). Visual persistence and illusory contours. Paper presented at the meeting of the Association for Research in Vision and Ophthalmology, Sarasota, FL. 1FD

MEYER, G. E., \& DougheRTY, T. (1987a). Effects of flickerinduced depth on chromatic subjective contours. Journal of Experimental Psychology: Human Perception \& Performance, 13, 353-360. 1C2D

MEYER, G. E., \& DOUGHERTY, T. J. (1987b, November). Sawtooth Pacpeople and the realization of illusory edges: Computational, cognitive, and utilitarian implications. Paper presented at the meeting of the Psychonomic Society, Seattle, WA. 1FDF2OHG

MEYER, G. E., \& DougrerTY, T. J. (1988a). Ambiguous fluidity/ rigidity and diamonds that ooze. Perception, 17, 401. 1FD2OH

MEYer, G. E., \& DougherTY, T. J. (1988b). Sawtooth "Pacpeople," fuzzy illusory edges, and contours that contract. Perception, 17, 364-365. 2OHDG

MEYER, G. E., FISH, D. (1986). Textural segregation and subjective contours. Perception \& Psychophysics, 39, 221. (Abstract) 1FD2OHG

MeYER, G. E., \& FISH, D. (1987). Mlusory contours, texture segre- gation, and a configural inferiority effect. In S. Petry \& G. E Meyer (Eds.), The perception of illusory contours (pp. 224-234). New York/Berlin: Springer-Verlag. 1FD2OHG

Meyer, G. E., Garges, C. (1979). Subjective contours and the Poggendorff illusion. Perception \& Psychophysics, 26, 302-304. 1C3IL

MeYer, G. E., Ming, C. Y. (1988). The visible persistence of illusory contours. Canadian Joumal of Psychology, 42, 479-488. $1 \mathrm{C} 2 \mathrm{OH}$

Meyer, G. E., \& Petry, S. (1987). Top-down and bottom-up: The illusory contour as a microcosm of issues in perception. In S. Petry \& G. E. Meyer (Eds.), The perception of illusory contours (pp. 3-20). New York/Berlin: Springer-Verlag. Review

Meyer, G. E., \& Philuips, D. (1980). Faces, vases, subjective contours and the McCollough effect. Perception, 9, 603-606. 2G

MEYer, G. E., \& SENECAL, M. (1983). The illusion of transparency and chromatic subjective contours. Perception \& Psychophysics, 34, 58-64. 2DAS3T

Micella, F., Pinna, B., \& Sambin, M. (1985). Segregazione di profonditd in figure anomale con differente grado di evidenza [Depth segregation in anomalous figures with a varying degree of salience]. Paper presented at the meeting of the Divisione Ricerca di Base in Psicologia, Ravello, Italy. 2D

Minguzzı, G. F. (1984). La percezione di superfici anomale [The perception of anomalous surfaces]. In G. Kanizsa (Ed.), Fenomenologia sperimentale della visione (pp. 97-118). Milan: Angeli. Review

MinguzzI, G. F. (1985). Figure anomale: Le modificazioni di chiarezza indotte da fine di linea [Anomalous figures: Brightness modifications induced by line ends]. In W. Gerbino (Ed.), Conoscenza e struttura: Festschrift per Gaetano Kanizsa (pp. 333. 351). Bologna: Il Mulino. 2AGAS

Minguzzi, G. F. (1986). Amodal figures and the tendency toward continuation. Perception \& Psychophysics, 39, 221. (Abstract) 1FD2DAG

Minguzzi, G. F. (1987). Anomalous figures and the tendency to continuation. In S. Petry \& G. E. Meyer (Eds.), The perception of illusory contours (pp. 71-75). New York/Berlin: SpringerVerlag. 1FD2DAG

MOR, G. F. (1959). Is it possible to measure the contrast enhancement of a figure with "quasi-perceptive contours"? Atti della Fondazione "Giorgio Ronchi," 14, 137-139. 1C

MORI, G. F., RoNCHI, L. (1960). On the perception of incomplete borders. Atti della Fondazione "Giorgio Ronchi," 15 , 357-368. 2G

Mulvanny, P., MacArthur, R., Sekuler, R. (1982). Thresholds for seeing visual phantoms and moving gratings. Perception, 11, 35-46. 1FDC2G

Mustillo, P., \& Fox, R. (1986). The perception of illusory contours in the hypercyclopean domain. Perception \& Psychophysics, 40, 362-363. 1FDC2OHD

Nakayama, K., Shimojo, S., \& Ramachandran, V. S. (1990). Transparency: Its relation to depth, subjective contours and neon color spreading. Perception, 19, 497-513. 2D3NCT

OEHLER, R., \& SPILlMANN, L. (1981). Illusory colour changes in Hermann grids varying only in hue. Vision Research, 21, 527-541. 1C3HG

OHMURA, H. (1981). Effects of subjective contours in stroboscopic motion. Japanese Journal of Psychology, 52, 233-239. 2G

OsGOOD, C. E. (1953). Method and theory in experimental psychology. New York: Oxford University Press. Review

OzoG, G. J. (1980). Quantitative measures of subjective contours. Dissertation Abstracts International, 40, 5443. ICF

PANIGHINI, A. (1982). Problemi nella formazione di figure anomale [Problems in the formation of anomalous figures]. Unpublished tesi di laurea [honors thesis], University of Padua, Department of Psychology. 2AG

Paradiso, M. A., Shimojo, S., \& Nakayama, K. (1989). Subjec- 
tive contours, tilt aftereffects, and visual cortical organization. Vision Research, 29, 1205-1213. 1FD3IL

PARKs, T. E. (1979). Subjective figures: Does brightness enhancement depend upon wubjective boundary definition? Perception \& Psychophysics, 26, 418. 1C

PARKs, T. E. (1980a). Comment on: "Sensory conditions for the occurrence of the neon spreading illusion." Perception, 9, 109. 3NC PARKS, T. E. (1980b). Letter to the editor. Perception, 9, 723.

PArks, T. E. $(1980 \mathrm{c})$. The subjective brightness of illusory figures: Is stratification a factor? Perception, 9, 361-363. 2D

PARKs, T. E. (1980d). Subjective figures: Some unusual concomitant brightness effects. Perception, 9, 239-241. IC

Parks, T. E. (1981). Subjective figures: An infrequent, but certainly not unprecedented, effect. Perception, 10, 589-590. 30

PARKs, T. E. (1982a). Brightness effects in diffuse and sharp illusory figures of similar configuration. Perception, 11, 107-110. 1FDC

Parks, T. E. (1982b). Humour. Perception, 11, 240.

PARKs, T. E. (1982c). Illusory contours: On the efficacy of their need for expression. Perception \& Psychophysics, 32, 286-289. IC

PARKs, T. E. (1983). Further difficulties for the filtered-components approach to illusory visual contours. Perception \& Psychophysics, 34, 190-192. 1F

Parks, T. E. (1984). Illusory figures: A (mostly) atheoretical review. Psychological Bulletin, 95, 282-300. Review

PARKs, T. E. (1985). Apparent depth and texture differences in illusory figure patterns: A paradox resolved. Perception \& Psychophysics, 37, 568-570. 2D

PARKs, T. E. (1986a). Illusory figures, illusory objects, and real objects. Psychological Review, 93, 207-215. 2DG

PARKs, T. [E.] (1986b). Illusory figures and pictorial objects. Perception \& Psychophysics, 39, 214. (Abstract) 2OH

PARKS, T. E. (1987). Illusory figures and pictorial objects. In S. Petry \& G. E. Meyer (Eds.), The perception of illusory contours (pp. 76-80). New York/Berlin: Springer-Verlag. 2OH

PARKS, T. E. (1987). On the relative frequency of depth effects in real versus illusory figures. Perception \& Psychophysics, 42 , 333-336. 2D

PARKS, T. E. (1989). Illusory-figure lightness: Evidence for a twocomponent theory. Perception, 18, 783-788. 2AS

Parks, T. E., \& Marks, W. (1983). Sharp-edged vs. diffuse illusory circles: The effects of varying luminance. Perception \& Psychophysics, 33, 172-176. 1C

PARKS, T. E., MARKs, W. (1985). Illusory figures: Individual differences in apparent depth and lightness. Perception \& Psychophysics, 37, 529-532. 1C2D

Parks, T. E., Pendergrass, L. (1982). On the filteredcomponents approach to illusory visual contours. Perception \& Psychophysics, 32, 491-493. 1F

PARKs, T. E., \& ROCK, I. (1990). Illusory contours from pictorially three-dimensional inducing elements. Perception, 19, 119-121. $1 \mathrm{C} 2 \mathrm{G}$

Parks, T. E., Rock, I., \& ANson, R. (1983). Illusory contour lightness: A neglected possibility. Perception, 12, 43-47, 1C2G

PASTORE, N. (1974). Cognitive subjective. Nature, 248, 719-720. 3IL

Perussia, F. (1980). Contributo sperimentale al problema della valutazione psicofisica del completamento amodale [Experimental contribution to the problem of psychophysical measurement of amodal completion]. In Reports from the Institute of Psychology (pp. 29-38). Milan: University of Milan, Medical Faculty. 2A

Perussia, F. (1984). L'espansione fenomenica in funzione del completamento amodale con superfici anomale [Phenomenal expansion in the case of amodal completion with anomalous surfaces]. In G. Kanizsa (Ed.), Fenomenologia sperimentale della visione (pp. 187-193). Milan. 2A
Peterhans, E., \& von der Heydt, R. (1988). Anomalous-contour responses and effects of common motion in V2 of the alert monkey-correlation with the cytochrome oxidase pattern. European Brain and Behavior Society Workshop, Tübingen. IFD

Peterhans, E., von Der HeYdT, R. (1989). Mechanisms of contour perception in monkey visual cortex: II. Contours bridging gaps. Journal of Neuroscience, 9, 1749-1763. 1FD

Peterhans, E., von der Heydt, R., \& Baumgartner, G. (1986). Neuronal responses to illusory contour stimuli reveal stages of visual cortical processing. In J. D. Pettigrew, K. J. Sanderson, \& W. R. Levick (Eds.), Visual neuroscience. Cambridge: Cambridge University Press. 1FD

Petersik, J. T. (1987). Dependence of apparent movement of a subjective figure on the perceptual fate of inducing elements. Perception, 16, 453-459. 2G

Petersix, J. T., Hicks, K. I., \& Pantle, A. J. (1978). Apparent movement of successively generated subjective figures. Perception, 7, 371-383. 2G

Petry, S., Gannon, R. (1987). Time, motion, and objectness in illusory contours. In S. Petry \& G. E. Meyer (Eds.), The perception of illusory contours (pp. 193-200). New York/Berlin: Springer-Verlag. 1FDC2OH

Petry, S., Gannon, R., \& Dailey, M. (1986). The effect of temporal manipulations on subjective contour strength. Perception \& Psychophysics, 39, 217. (Abstract) 1FDG2OHD

Petry, S., Harbeck, A., Conway, J., Levey, J. (1983). Stimulus determinants of brightness and distinctness of subjective contours. Perception \& Psychophysics, 34, 169-174. 1FDC2OH

Petry, S., \& McShane, R. (1987). Illusory countours can generate illusory contours. In Fourth International Conference on Event Perception and Action (p. 148). Trieste. (Abstract) 1FDC2OH

Petry, S., \& MeYer, G. E. (1986). Adelphi international conference on illusory contours: A report on the conference. Perception \& Psychophysics, 39, 210. (Abstract) Review

Petry, S., \& Meyer, G. E. (Eds.) (1987a). The perception of illusory contours. New York/Berlin: Springer-Verlag. Review

Petry, S., MeYer, G. E. (1987b). Subjective contour humour. Perception, 16, 223-224.

Petter, G., Tessari, F. (1985). I fenomeno dei margini anomali in bambini dai 3 ai 10 anni [The perception of subjective contours in 3- to 10-year-old children]. In W. Gerbino (Ed.), Conoscenza e struttura: Festschrift per Gaetano Kanizsa (pp. 401-424). Bologna: Il Mulino. 2ADV

Piggins, D. J. (1975). Cognitive space. Perception, 4, 337-340. 2OHD

PINNA, B. (1987). Un effetto di colorazione [A color effect]. In Atti del XXI Congresso degli Psicologi Italiani "Il Laboratorio

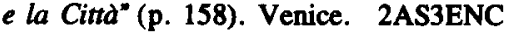

PinNa, B. (1989). Superfici anomale: Forma, chiarezza e profondità [Anomalous surfaces: Shape, brightness and depth]. In Contributi dei dipartimenti e degli istituti ltaliani di Psicologia. Padua: University of Padua. 2DAAS

PinNA, B. (1991). Anomalous contours and illusion of angularity: Phenomenal and theoretical comparisons. Perception, 20, $207-$ 218. 2OH3IL

Pinna, B., \& SAMbin, M. (1991). A dynamic model for anomalous figures: The shape of line-induced brightness modification. Perception, 20, 219-232. 1GAS

Pomerantz, J. R., Goldberg, D. M., Golder, P. S., \& TETEWSKI, S. (1981). Subjective contours can facilitate performance in a reaction-time task. Perception \& Psychophysics, 29, 605-611. 1FD30

Porac, C. (1978). Depth in objective and subjective contour patterns. Bulletin of the Psychonomic Society, 11, 103-105. 2D Prandte, A. (1927). Über gleichsinnige Induktion und die Lichter- 
teilung im gitterartigen Munstern. Zeitschrift fur Sinnesphysiologie, 58, 263-307. 1C2G

Prazdny, K. (1983). Illusory contours are not caused by simultaneous brightness contrast. Perception \& Psychophysics, 34, 403 404. $1 \mathrm{C}$

Prazdny, K. (1985). On the nature of inducing forms generating perceptions of illusory contours. Perception \& Psychophysics, 37, 237-242. 1FDC2D

Prazdny, K. (1986a). Capture of stereopsis by illusory contours. Nature, 324, 393. 2DG

Prazdny, K. (1986b). Illusory contours from inducers defined solely by spatiotemporal correlation. Perception \& Psychophysics, 39, 175-178. 1C2OHD

Prazdny, K. (1986c). Illusory contour phenomena from inducing elements defined solely by spatiotemporal correlation. Perception \& Psychophysics, 39, 218. (Abstract) 1FD2D

Predebon, J. (1985). Illusory contours and size illusions. Bulletin of the Psychonomic Saciety, 23, 47-49. 2D

Prinzmetal, W., Keysar, B. (1989). Functional theory of illusory conjunctions and neon colors. Journal of Experimental Psychology: General, 118, 165-190. 3NC

PritCHARD, W. S. (1982). Effects of divided attention on pattern discrimination with real and subjective contour figures. Dissertation Abstracts International, 43, $1646 . \quad 1 F D 2030$

PrITCHARD, W. S. (1986). Reductionism versus holism: Levels of explanation and the subjective contour illusion. Perception \& Psychophysics, 39, 214. (Abstract) 30

Pritchard, W. S., \& WARM, J. S. (1983). Attentional processing and the subjective contours illusion. Journal of Experimental Psychology: General, 112, 145-175. $10 \mathrm{HO}$

Purghe, F. (1987). Some orientational effects on subjective contours and anomalous surfaces formation. In Fourth International Conference on Event Perception and Action (p. 10). Trieste. (Abstract) 1FDC

PuRGHÉ, F. (1988). The role of figural incompleteness and brightness contrast in the formation of anomalous surfaces. Perception, 17, 365. 1AAS

Purghé, F. (1989a). Privileged directions for subjective contours: Horizontal and vertical versus tilted. Perception, 18, 201-213. IC2GAS

PURGHÉ, F. (1989b). In ruolo dell'incompletezza figurale e del completamento amodale nella formazione di superfici anomale [The role of figural incompleteness and amodal completion in the formation of anomalous surfaces]. Giomale ltaliano di Psicologia, 16, 101-118. 2A

PURGHÉ, F. (1990). Le superfici anomale e il modello di Kanizsa: Il completamento amodale e realmente un fattore necessario? [Anomalous surfaces and Kanizsa's theory: Is amodal completion a necessary factor?]. Rivista di Psicologia, 2, 5-17. 2A

PuRghí, F. (in press-a). Is amodal completion necessary to the formation of illusory figures? Perception. 2DA

Purghé, F. (in press-b). La percezione dell'incompletezza figurale: Un'ipotesi fenomenologica [The perception of figural incompleteness: A phenomenological hypothesis]. Giornale Italiano di Psicologia. 2G

Purghé, F., \& COREN, S. (1991). The perception of subjective contours. Perception, 20, 179-180. Review

Purghé, F., \& Katsaras, P. (1991). Figural conditions affecting the formation of anomalous surfaces: An overall configuration vs. a simple stimulus part factor. Perception, 20, 193-206. IC2AG

RAMACHANDRAN, V. S. (1985). Apparent motion of subjective surfaces. Perception, 14, 127-134. 1FD2G

Ramachandran, V. S. (1986a). Capture of stereopsis and apparent motion by illusory contours. Perception \& Psychophysics, 39, 361-373. 1FD2GC

Ramachandran, V. S. (1986b). Capture of stereopsis by illusory contours: Reply. Nature, 324, 393-394. 1FD2GC
RAMACHANDRAN, V. S. (1986c). What does the brain do with illusory contours? Perception \& Psychophysics, 39, 216. (Abstract) 1FD2DGC

Ramachandran, V. S. (1987). Visual perception of surfaces: A biological theory. In S. Petry \& G. E. Meyer (Eds.), The perception of illusory contours (pp. 93-108). New York/Berlin: Springer-Verlag. 1FD2DGC

Ramachandran, V. S., Cavanagh, P. (1985). Subjective contours capture stereopsis. Nature, 317, 527-530. 1FD2DG

Ramachandran, V. S., Inada, Y., Kiama, G. (1986). Perception of illusory occlusion in apparent motion. Vision Research, 26, 1741-1749. 1FD2OHDC

Ramachandran, V. S., Rao, V. M., * Vidyasagar, T. R. (1973). Apparent movement with subjective contours. Vision Research, 13, 1399-1401. 1FD2OH

Redies, C. (1989). Discontinuities along lines: Psychophysics and neurophysiology. Neuroscience \& Biobehavioral Reviews, 13. 17-22. 1FDC3E

Redies, C., Crook, J. M., \& Creutzfeld, O. D. (1986). Neuronal responses to border with and without luminance gradients in cat visual cortex and dorsal lateral geniculate nucleus. $E x$ perimental Brain Research, 61, 469-481. IFDC3EO

Redies, C., \& SpillmanN, L. (1981). The neon color effect in the Ehrenstein illusion. Perception, 10, 667-681. 1FDC3NCE

Redies, C., Spillmann, L., Kunz, K. (1984). Colored neon flanks and line gap enhancement. Vision Research, 24, 1301-1309. 1FDC3ENC

Remole, A., Ng, A. S. Y., BAthe, L. L., Padfeld, P. D., SPAFFoRD, M. M., \& SzYMKTw, M. A. (1985). Flicker haloes observed with subjective borders. Perception, 14, 31-40. 1FDC2G

REYNOLDS, R. I. (1981). Perception of an illusory contour as a function of processing time. Perception, 10, 107-115. 20H3T

Richardson, B. L. (1979). The nonequivalence of abrupt and diffuse illusory contours. Perception, 8, 589-593. IFD2OH

Richardson, B. L. (1981). Subjective figures: Some not-so-unusual concomitant brightness effects. Perception, 10,587-588. 1C2GD

RichARDSON, B. L., \& WILlemin, D. B. (1981). Illusory contours not accompanied by a brightness gradient. Italian Journal of Psychology, 8, 201-207. 1C2DG

Rock, I. (1986). Cognitive intervention in perceptual processing. Perception \& Psychophysics, 39, 213. (Abstract) 2OH

Rock, I. (1987). A problem-solving approach to illusory contours. In S. Petry \& G. E. Meyer (Eds.), The perception of illusory contours (pp. 62-70). New York/Berlin: Springer-Verlag. 2OH

Rock, I., ANSON, R. (1979). Illusory contours as the solution to a problem. Perception, 8, 665-681. 2OH

RoNCHI, L., MORI, G. F. (1959). On the factors which affect the contrast enhancement in a figure with "quasi-perceptive contours" and a practical application of such a figure. Atti della Fondazione "Giorgio Ronchi," 14, 495-508. 1C

RowbURY, C. R. (1982). A comment on Day and Jory's note on a second stage in the formation of illusory contours. Perception \& Psychophysics, 31, 395-396. 2G

SACK, N., \& HAAF, R. (1986). Infant perception of subjective contours. Ohio Journal of Science, 86, 37. 2DDV

Salzman, B. (1982). Assessing the contribution of cognitive and retinal factors in the perception of abrupt and diffuse subjective contours. Dissertation Abstracts International, 43, 3395. 1FDC2G

Salzman, B., HalPERN, D. F. (1982). Subjective towers: Depth relationships in multilevel subjective contours. Perceptual \& Motor Skills, 55, 1247-1256. 2D

Sambin, M. (1974a). L'ambito di influenza delle tensioni terminali nell'organizzazione di figure senza gradiente [nfluence and limits of terminal tensions in the organization of figures without gradient]. Rivista di Psicologia, 68, 257-264. 2GASO3E

SAMBin, M. (1974b). Angular margins without gradient. Italian Journal of Psychology, 1, 355-361. 2GASO3E 
SAMBin, M. (1974c). Superfici senza gradiente e "ipotesi di oggetto" [Surfaces without gradient and "object hypothesis"']. Atti dell'7stituto veneto di science, lettere e arti, 132, 645-651. $2 \mathrm{OH}$

Sambin, M. (1975). The rule of terminal tensions in the organization of margins without gradient. Italian Journal of Psychology, 2, 239-257. 2ASO3E

SAMBIN, M. (1977). Contours without gradient with different phenomenal evidence. Giornale Italiano di Psicologia, 4, 121-147. 2ASO3E

SAMBin, M. (1978). Il contrasto di chiarezza nelle figure anomale [Brightness contrast in anomalous surfaces]. Giornale Italiano di Psicologia, 5, 543-565. 1C2G

SAMBIN, M. (1980a). Le disomogeneità indotte nella formazione di margini e superfici anomale [Induced inhomogeneities in the formation of subjective contours and anomalous surfaces]. In Reports from the Institute of Psychology (pp. 1-33). Trieste: University of Trieste. $1 \mathrm{C} 2 \mathrm{G}$

SAmbIN, M. (1980b). Figure anomale: Il contrasto di chiarezza come risultato delle disomogeneita indotte [Anomalous figures: Brightness contrast as a result of induced inhomogeneities]. Giornale Italiano di Psicologia, 7, 121-149. 1C2GAS

SAMBIN, M. (1981a). Figure anomale: La polarizzazione intrafigurale delle parti inducenti [Anomalous figures: The intrafigural polarization of inducing parts]. Giomale Italiano di Psicologia, 8, 421-436. 2G

SAMBIN, M. (1981b). On the threshold measurement of anomalous figures (Rep. No. 30, pp. 1-16). Padua: University of Padua, Institute of Psychology. 1C3E

SAmbin, M. (1983). Trasparenza con superfici indotte [Transparency with induced surfaces]. Giornale Italiano di Psicologia, 10, 543-556. 2G3T

SAmBin, M. (1985). Figure anomale: La misura dell'ampiezza di una disomogeneità indotta [Anomalous figures: The measurement of an induced inhomogeneity's size]. In W. Gerbino (Ed.), Conoscenza e struttura: Festschrift per Gaetano Kanizsa (pp. 437 452). Bologna: Il Mulino. 2GAS3E

SAmbin, M. (1986). Subjective figures: The measurement of homogeneity induced by lines. Perception \& Psychophysics, 39, 218-219. (Abstract) 2G3E

Sambin, M. (1987). A dynamic model of anomalous figures. In S. Petry \& G. E. Meyer (Eds.), The perception of illusory contours (pp. 131-142). New York/Berlin: Springer-Verlag. 2G3E

SAMBIN, M., \& PINNA, B. (1986). Ulteriori caratteristiche delle linee inducenti figure anomale [Further characteristics of lines inducing anomalous figures]. Giornale Italiano di Psicologia, 13, 89-100. 2GAS3E

SAmbin, M., Rocco, D. (1987). Punti di ancoramento nella formazione di figure anomale [Anchoring points in the formation of anomalous figures]. Giornale ttaliano di Psicologia, 14, 589-607. 2GAS3E

SATO, T. (1983). Depth seen with subjective contours. Japanese Psychological Research, 25, 213-221. 2D

Savardi, U., SAviolo, M. (1984). Effect of adaptation to a bright/dark field on the Hermann grid illusion. Ricerche di Psicologia, 3, 89-97. 1FDC3HG

SchraUf, M., Ehrenstern, W. H. (1990). Visual persistence of subjective contours produced by random-dot motion-contrast stimuli. Perception, 19, 411. 1FDC

Schumann, F. (1900). Beiträge zur Analyse der Gesichtswahrnehmungen: Erste Abhandlung. Einige Beobachtungen über die Zusammenfassung von Gesichtseindrücken zu Einheiten. Zeitschrift fur Psychologie und Physiologie der Sinnesorgane, 23, 1-32. [Also published as Contributions to the analysis of visual perception: First paper. Some observations on the combination of visual impressions into units, trans. A. Hogg, in S. Petry \&
G. E. Meyer (Eds.), The perception of illusory contours (pp. 2134). New York/Berlin: Springer-Verlag.] 2G

SchumanN, F. (1904). Einige Beobachtungen über die Zusammenfassung von Gesichtseindrücken zu Binheiten [Some observations on the combination of visual impressions into units]. Psychologische Studien, 1, 1-32. 2OHG

Shank, M. D., \& WALkER, J. T. (1989). Figure-ground organization in real and subjective contours: $A$ new ambiguous figure, some novel measures of ambiguity, and apparent distance across regions of figure and ground. Perception \& Psychophysics, 46, 127-138. 1C2DG3O

SHAPLEY, R., * GoRDON, J. (1986). Neural mechanisms of subjective contours. Perception \& Psychophysics, 39, 214-215. (Abstract) 1FDCF2A

SHAPLEY, R., GoRDON, J. (1987). The existence of interpolated illusory contours depends on contrast and spatial separation. In S. Petry \& G. E. Meyer (Eds.), The perception of illusory contours (pp. 109-115). New York/Berlin: Springer-Verlag. 1FDCF2A

ShIPLEY, T. F. (1965). Visual contours in homogeneous space. Science, 150, 348-350. 1FD

SHIPLEY, T. F. (1989). Unit formation in subjective contour perception: Evidence for a discontinuity theory. Dissertation Abstracts International, 49, 4048. 2DGC

Shipley, T. F., Kellman, P. J. (1990). The role of discontinuities in the perception of subjective figures. Perception \& Psychophysics, 48, 259-270. 2OHAGC

SiEgel, S., \& Petry, S. (1991). Evidence for independent processing of subjective contour brightness and sharpness. Perception, 20, 233-242. 1FDC

Silltto, A., Gregory, R. L., \& HeArD, P. (1982). Can cognitive contours con cat cortex? Paper presented to the Experimental Psychology Meeting, St. Andrews, Scotland. IFD3O

Summonds, M. B. (1974). Stereopsis and subjective contours. Perception \& Psychophysics, 15, 401-404. 2D

SMTTH, K. A. (1983). Evidence relating subjective contours and interpretations involving interposition. Perception, 12, 491-500. 2D

Smith, A. T., OVER, R. (1975). Tilt aftereffects with subjective contours. Nature, 257, 581-582. 1FD3IL

Smith, A. T., \& Over, R. (1976). Color-selective tilt aftereffects with subjective contours. Perception \& Psychophysics, 20, 305308. 1FD3IL

SMITH, A. T., OVER, R. (1977). Orientation masking and the tilt illusion with subjective contours. Perception, 6, 441-447. IFD3IL

SMITH, A. T., * OvER, R. (1979). Motion aftereffect with subjective contours. Perception \& Psychophysics, 25, 95-98. 1FD2D3IL

Soubitez, M. C. (1982). Perceptual development of the Ehrenstein illusion in children. Perception, 11, A33. 3E

SpillmanN, L. A. (1971). Foveal perceptive fields in the human visual system measured with simultaneous contrast in grids and bars. Pflugers Archives, 326, 281-299. 1FDC3HG

Spillmann, L. A. (1975). Perceptual modification of the Ehrenstein Illusion. In S. Ertel, L. Kemmler, \& M. Stadler (Eds.), Gestaltheorie in der modernen Psychologie (pp. 210-218). Darmstadt: Steinkopff. 1FDC3E

SpillmanN, L. A. (1977). Contrast and brightness in illusions. In H. Spekreijse \& L. H. van der Tweel (Eds.), Spatial contrast (pp. 45-49). Amsterdam/New York: North-Holland. IFDC3HGE

SpillmanN, L. A., Levine, J. (1971). Contrast enhancement in a Hermann grid with variable figure-ground ratio. Experimental Brain Research, 13, 547-559. 1FDC3HG

SpillmanN, L. A., \& Redes, C. (1981). Random-dot motion displaces Ehrenstein illusion. Perception, 10, 411-415. 1FD2G3HG

Spillmann, L. A., Fuld, K., \& Gerrits, H. J. M. (1976). Brightness contrast in the Ehrenstein illusion. Vision Research, 16, 713-719. 1FDC3E

SpillmanN, L. A., Fuld, K., \& Neumeyer, C. (1984). Bright- 
ness matching, brightness cancellation, and increment threshold in the Ehrenstein illusion. Perception, 13, 513-520. 1FDC3E

StADler, M., \& DiekER, J. (1969). Margini quasi-percettivi e aftereffects figurali [Quasiperceptive margins and figural aftereffects]. Rivista di Psicologia, 63, 95-104. 1FD3IL

Stadler, M., \&ieker, J. (1972). Untersuchungen zum Problem virtueller Konturen in der Visuellen Wahrnemung [Investigations of the problem of virtual contours in visual perception]. Zeitschrift fur experimentelle und angewandte Physiologie, 19, 325-350. IC

STAPPERS, P. J. (1989). Forms can be recognized from dynamic occlusion alone. Perceptual \& Motor Skills, 68, 243-251. 2OHD

Stevens, K. A. (1983). Evidence relating subjective contours and interpretations involving interposition. Perception, 12, 491-500. 2 OHDG3O

Streibel, M. J., Barnes, R. D., Julness, G. D., \& Ebenholtz, S. M. (1980). Determinants of the rod-and-frame effect: Role of organization and subjective contour. Perception \& Psychophysics, 27, 136-140. 1C2G3IL

TINNEY, L. M. (1988). Can real and illusory contours be attributed to similar neural processes? Unpublished honours report, Department of Psychology, Monash University, Melbourne, Australia. 1FD3IL

Toso, L. L. (1983). Illusory contour perception in young children. Unpublished honours report, Department of Psychology, Monash University, Melbourne, Australia. 2GADV3NC

Treiber, F., \& Wilcox, S. (1980). Perception of a "subjective" contour by infants. Child Development, 51, 915-917. 2ODV

Troscianko, T. (1982). A stereoscopic presentation of the Hermann grid. Vision Research, 22, 485-489. IFDC3HG

TYLER, C. N. (1977). Is the illusory triangle physical or imaginary? Perception, 6, 603-604. 1FD2C

Tynan, P., \& Sexuler, R. (1975). Moving visual phantoms: A new contour completion effect. Science, 188, 951-952. 1FD2G

Ullman, S. (1976). Filling-in the gaps: The shape of subjective contours and a model for their generation. Biological Cybernetics, 25, 1-6. 1FD2C

VallortigarA, G. (1987). The hidden face of Kanizsa's triangle: Apparent movement of subjective figures in three-dimensional space. Perception, 16, 449-452. 2OHD

Van Tuiv,, H. F. J. M. (1975). A new visual illusion: Neonlike color spreading and complementary color induction between subjective contours. Acta Psychologica, 39, 441-445. 2AS3NC

VAN TuiJl, H. F. J. M., DE WeERT, C. M. M. (1979). Sensory conditions for the occurrence of the neon spreading illusion. Perception, 8, 211-215. 1C2AS3NC

VAN TuiJl, H. F. J. M., \& DE WEeRT, C. M. M. (1980). Reply to Parks. Perception, 9, 111-112. 1C2AS3NC

VAn Tuijl, H. F. J. M., \& Leeuwenberg, E. L. J. (1979). Neon color spreading and structural information measures. Perception \& Psychophysics, 25, 269-284. 2CO3NC

Van TuiJl, H. F. J. M., \& Leeuwenberg, E. L. J. (1982). Peripheral and central determinants of subjective contour strength. In H. G. Geissler \& P. Petzold (Eds.), Psychological judgment and the process of perception. Berlin: VEB Deutscher Verlag der Wissenshaften. 1FDC2OHDG

VARIN, D. (1971). Fenomeni di contrasto e diffusione cromatica nell'organizzazione spaziale del campo percettivo [Contrast and color spreading phenomena in the spatial organization of the perceptual field]. Rivista di Psicologia, 65, 101-128. 2AGAS3NC

Vogels, R., ORBAN, G. A. (1985). How finely can we judge the orientation of an illusory contour? Archives Internationales de Physiologie et de Biochimie, 93, P6-P7. 1FD3O

Vogels, R., ORBAN, G. A. (1987). Ilusory contour orientation discrimination. Vision Research, 27, 453-467. 1FD3O

VON DER HeYdT, R., PETERHANS, E. (1989). Mechanisms of contour perception in monkey visual cortex: I. Lines of pattern discontinuity. Journal of Neuroscience, 9, 1731-1748. 1FDC
Von der Heydt, R., Peterhans, E. (1989). Mechanisms of contour perception in monkey visual cortex: II. Contours bridging gaps. Journal of Neuroscience, 9, 1749-1763. 1FD2G

Von der Heydt, R., Peterhans, E., \& Baumgartner, G. (1984). Illusory contours and cortical neuron responses. Science, 224, 1260-1262. 1FD

Von GrünaU, M. W. (1979). The involvement of illusory contours in stroboscopic motion. Perception \& Psychophysics, 25, 205-208. 1FD2G3E

W ADE, N. [J.] (1986). Allusory contours. Perception \& Psychophysics, 39, 221. (Abstract) 2G

WADE, N. J. (1987). Allusory contours. In S. Petry \& G. E. Meyer (Eds.), The perception of illusory contours (pp. 274-294). New York/Berlin: Springer-Verlag. $2 \mathrm{G}$

WADE, N. J. (1990). Visual allusion: Pictures of perception. Hove, U.K.: Erlbaum. Review

Wagemans, J., D'YDEWALle, G. (1989). The effect of kinetic occlusion and categorization on amodal completion: A comment on Gerbino e Salmaso (1987). Acta Psychologica, 72, 281-293. 2OHD

WALKER, J. T. (1987). Dinosaurs, nuclear winter, and Kanizsa figures: In defense of pure science and intellectual curiosity. Teaching of Psychology, 14, 48-50. 30

Walker, J. T., Shank, M. D. (1987). The Bourdon illusion in subjective contours. Perception \& Psychophysics, 42, 15-24. 1FD3IL

WALKer, J. T., \&hank, M. D. (1988a). Interactions between real and subjective contours in the Bourdon illusion. Perception \& Psychophysics, 43, 567-574. 1FDC3IL

Walker, J. T., Shank, M. D. (1988b). Real and subjective lines and edges in the Bourdon illusion. Perception \& Psychophysics, 43, 475-484. IFDC3IL

Wallace, B., Persanyi, M. W., Gerboc, B. (1989). Imagery, hypnosis, and the creation of subjective contours. Journal of Mental Imagery, 13, 139-151. 30

Wallach, H., Slaughter, V. (1988). The role of memory in perceiving subjective contours. Perception \& Psychophysics, 43, 101-106. 2OH

WARE, C. (1980). Coloured illusory triangles due to assimilation. Perception, 9, 103-107. 2AS3NCT

WARE, C. (1981a). Brightness and colour effects occurring with subjective contours. Dissertation Abstracts International, 42, 416. 1C2GAS3T

W ARE, C. (1981b). Subjective contours independent of subjective brightness. Perception \& Psychophysics, 29, 500-504. 1C2G

WARE, C., \& KenNEdy, J. M. (1977). Ilusory line linking solid rods. Perception, 6, 601-602. 20

WARE, C., \& Kennedy, J. M. (1978). Perception of subjective lines, surfaces and volume in 3-dimensional constructions. Leonardo, 11, 111-114. 20

Warm, J. S., Dember, W. N., Padich, R. A., Beckner, J., \& JONES, S. (1986). Effects of luminance and inducing area on the apparent strength of subjective contours. Perception \& Psychophysics, 39, 219. (Abstract) 1C

WArm, J. S., Dember, W. N., PAdich, R. A., Beckner, J., JONES, S. (1987). The role of illumination level in the strength of subjective contours. In S. Petry \& G. E. Meyer (Eds.), The perception of illusory contours (pp. 176-182). New York/Berlin: Springer-Verlag. 1C

Wasserstein, J., Zappulla, R., Rosen, J., \&erstman, L. (1987). In search of closure: Subjective contour illusions, Gestalt completion tests, and implications. Brain \& Cognition, 6, 1-14. 1FD2G

Watanabe, T., \& Oyama, T. (1988). Are illusory contours a cause or a consequence of apparent differences in brightness and depth in the Kanizsa square? Perception, 17, 513-521. 1C2D

Watanabe, T., \& Sato, T. (1989). Effects of luminance contrast 
on color spreading and illusory contour in the neon color spreading effect. Perception \& Psychophysics, 45, 427-430. IC2AS3ENC

W ATANABE, T., \& TAKEICHI, H. (1990). The relation between color spreading and illusory contour's. Perception \& Psychophysics, 47, 457-467. 1FD2AS3ENC

Weisstein, N., Maguire, W., \& Berbaum, K. (1977). A phantommotion aftereffect. Science, 198, 955-958. 1FD3IL

Weisstein, N., Maguire, W., Williams, M. C. (1982). The effect of perceived depth of phantoms and the phantom motion aftereffect. In J. Beck (Ed.), Organization and representation in perception. Hillsdale, NJ: Erlbaum. 1FD2D3IL

Weisstein, N., Matthews, M. L., \& Berbaum, K. (1977). Illusory contours can mask real contours. Bulletin of the Psychonomic Society, 4, 266. (Abstract) 1FD

Wenderoth, P., Criss, G., \& van der Zwan, R. (1990). Determinants of subjective contour: Bourdon illusions and "unbending" effects. Perception \& Psychophysics, 48, 497-508. 3IL

Whitmore, C. L. G., LAwson, R. B., \& Kozora, C. E. (1976). Subjective contours in stereoscopic space. Perception \& Psychophysics, 19, 211-213. 2D
Wist, E. R. (1976). Dark adaptation and the Hermann grid illusion. Perception \& Psychophysics, 20, 10-12. 1FDC3HG

WolfE, J. M. (1984). Global factors in the Hermann grid illusion. Perception, 13, 33-40. 1FD3HG

WOODWORTH, R. S. (1938). Experimental psychology. New York: Henry Holt. Review

YonAs, A. (1978). The phenomenon of subjective contours. Leonardo, 11, 258. 1020

ZANFORLIN, M. (1981). Visual perception of complex forms (anomalous surfaces) in chicks. Italian Joumal of Psychology, 8, 1-16. 20

Zanforlin, M., Vallortigara, G. (1990). The magic wand: A new stereokinetic anomalous surface. Perception, 19, 410. 2OHG3NCT

Zhang, H.-C., \& Peng, T.-L. (1980). Subjective contours and depth cues. Acta Psychologica Sinica, 12, 63-67. 2D

(Manuscript received July 1, 1991; revision accepted for publication August 27, 1991.) 